\title{
Study on the Effect of Unilateral Sand Deposition on the Spatial Distribution and Temporal Evolution Pattern of Temperature beneath the Embankment
}

\author{
Ling Chen $\mathbb{D}^{1},{ }^{1,2}$ Hong Yu $\mathbb{D},{ }^{1,3}$ Xiaolin Li $\mathbb{D}^{4},{ }^{4}$ and Zekun Ding $\mathbb{D}^{1,2}$ \\ ${ }^{1}$ State Key Laboratory of Frozen Soils Engineering, Northwest Institute of Eco-Environment and Resources, \\ Chinese Academy of Sciences, Lanzhou Gansu 730000, China \\ ${ }^{2}$ University of Chinese Academy of Sciences, Beijing 100049, China \\ ${ }^{3}$ School of Civil Engineering, Lanzhou University of Technology., Lanzhou Gansu 730050, China \\ ${ }^{4}$ College of Civil Engineering and Architecture, Jiaxing University, Jiaxing 314001, China \\ Correspondence should be addressed to Ling Chen; chenling@lzb.ac.cn
}

Received 6 May 2021; Accepted 12 June 2021; Published 21 June 2021

Academic Editor: Hao Zheng

Copyright (c) 2021 Ling Chen et al. This is an open access article distributed under the Creative Commons Attribution License, which permits unrestricted use, distribution, and reproduction in any medium, provided the original work is properly cited.

\begin{abstract}
In the context of climate warming and the frequent wind-sand hazards in the Qinghai-Tibet Engineering Corridor (QTEC), the construction of the embankment will affect the thermal regime of permafrost underground. The influence of embankment construction on the variation of the permafrost table beneath it is different, especially for the regime with different mean annual ground temperatures (MAGTs). In this study, the effects of the unilateral sand particles deposition on the spatial distribution and temporal evolution pattern of temperature beneath the embankment are investigated through the numerical simulations, in which the heat transfer is considered. The model is validated by the field observed data of soil temperatures around an experimental zone built at the sand hazard area in Honglianghe, the interior of Qinghai-Tibet Plateau (QTP). The simulated results indicate that the temperature field beneath the embankment is asymmetrically distributed under the condition of unilateral sand particles deposition. This asymmetry gradually weakened with the increase of operation time and the gradual adjustment of the permafrost temperature field. By comparing the permafrost table beneath the natural surface, the sand deposition center, and the middle of the embankment center, it could be found that the unilateral sand particles deposition has less effect on the degradation of the permafrost table in the center of the embankment. However, for the center of the sand deposition, the change of the permafrost table is larger with the increase of time and the corresponding rate of permafrost table degradation is higher than that without sand particles deposition, especially for the high-temperature permafrost. In addition, with different sand thickness and width conditions, the effect of "narrow-thick" form sand particles deposition on the temperature field beneath embankment is greater than that of "wide-thin" form sand deposition. Hence, in order to reduce its impact on the long-term thermal condition beneath the embankment, it is necessary to clean the thicker deposition sand particles at the toe of the embankment.
\end{abstract}

\section{Introduction}

The Qinghai-Tibet Engineering Corridor (QTEC) is the most important link between the Tibet Autonomous Region and inner China, the width of which is several kilometers at wider sections but only hundreds of meters at narrow section [1]. Within the corridor, there are several major linear infrastructures including the Qinghai-Tibet Highway, QinghaiTibet Railway, Qinghai-Tibet Power Transmission Line, and
Golmud to Lhasa Oil Pipeline and some optical communication cables. In recent years, human activities and increasing air temperature have caused significant grassland degradation and desertification in the QTEC [2-5]. Following the impacts, particularly the construction of the highway and the railway embankments, the energy of near-surface wind flow within the corridor has been disturbed, as well as the original relatively stable sand movement [6]. Hence, the wind-sand hazards were very serious around the highway and railway 
embankments, particularly in some river valleys and basins that the highway and railway traverse (Figure 1).

In the permafrost, the construction of the embankment will disturb the heat balance of the original surface. The strong heat absorption of asphalt pavement will lead to more rapid permafrost degradation beneath the highway [7-9]. In addition, the change of the thermal-mechanical properties of permafrost will cause embankment and pavement damage, including longitudinal cracks and uneven settlement [10-12]. Hence, in order to reduce the impact of the human activities, a lot of effective engineering structural measures have been considered and used in the construction of highway and railway embankment including the crushed-rock and ductventilated embankments. Due to the excellence of the crushed-rock and duct-ventilated embankments, they have been widely used to ensure the thermal stability of highways and railways in permafrost regions of the QTEC [13-19]. However, in the context of climate warming and the expanding scope of human activities, the wind-sand hazards around the embankment in the QTEC have become more and more serious in the last few years [20-23]. The sand particles deposition around the embankment will not only change the surface boundary but also affect the cooling effect of the construction of crushed-rock or duct-ventilated embankments [24-26]. Research studies have shown that with the increasing thickness of sand in the rock layer, the critical temperature difference between the sand-free layer increases, and the Ra number decreases, and the natural convection intensity weakens gradually [27-30]. However, in these research studies, several assumptions about the sand deposition around the embankment are proposed. The distribution of sand particles deposition is generally assumed to be the same at the two slopes of the embankment. The prevailing wind direction within the corridor is west and northwest, and the corridor is from northeast to southwest [1]. Then, the two slopes of embankments of both the railway and highway are generally windward and leeward slopes, respectively. Thus, there should be a considerable difference in the sand deposition on the two slopes. However, the difference was not considered within these previous research studies, which will undermine the accuracy of evaluation on thermal impacts of sand particles deposition on the embankments installed with air-cooled structures.

In this study, a two-dimensional numerical model of the heat transfer for highway embankment is established. In the numerical model, three different mean annual ground temperatures (MAGTs) of the permafrost, in which the embankment is located, are considered, as well as the unilateral sand particles deposition at the toe of the embankment. Field observed data of soil temperatures around an experimental zone are used to validate the numerical model. Through numerical simulations, the effects of unilateral sand deposition on the spatial distribution and temporal evolution pattern of temperature beneath the embankment are investigated. The results of this study could provide informative references for highways constructed in permafrost zones, in which the wind-sand hazards frequently occur around the embankment.

\section{Methods}

2.1. Governing Equations. According to the experiment, in freeze-thaw soil layers, the ratio of heat conduction is far larger than that of the heat convention [31]. In this article, by ignoring the heat convection, the heat transfer progress considering the heat conduction and phase change in freezethaw soil layers can be described as follows [32-34]:

$$
C_{e}^{*} \frac{\partial T}{\partial t}=\frac{\partial}{\partial x}\left(\lambda_{e}^{*} \frac{\partial T}{\partial x}\right)+\frac{\partial}{\partial y}\left(\lambda_{e}^{*} \frac{\partial T}{\partial y}\right),
$$

where $C_{e}^{*}$ is the equivalent volume heat capacity and $\lambda_{e}^{*}$ is the equivalent thermal conductivity. According to the method of sensible heat capacity, the equivalent volume heat capacity $C_{e}^{*}$ and the equivalent thermal conductivity $\lambda_{e}^{*}$ in freezethaw soils can be written as follows [32-34]:

$$
\begin{gathered}
C_{e}^{*}= \begin{cases}C_{f}, & T<\left(T_{m}-\Delta T\right), \\
\frac{L}{2 \Delta T}+\frac{C_{u}+C_{f}}{2}, & \left(T_{m}-\Delta T\right) \leq T \leq\left(T_{m}+\Delta T\right), \\
C_{u}, & T>\left(T_{m}+\Delta T^{*}\right),\end{cases} \\
\lambda_{e}^{*}= \begin{cases}\lambda_{f}, & T<\left(T_{m}-\Delta T\right), \\
\lambda_{f}+\frac{\lambda_{u}-\lambda_{f}}{2 \Delta T}\left[T-\left(T_{m}-\Delta T\right)\right], & \left(T_{m}-\Delta T\right) \leq T \leq\left(T_{m}+\Delta T\right), \\
\lambda_{u}, & T>\left(T_{m}+\Delta T\right),\end{cases}
\end{gathered}
$$




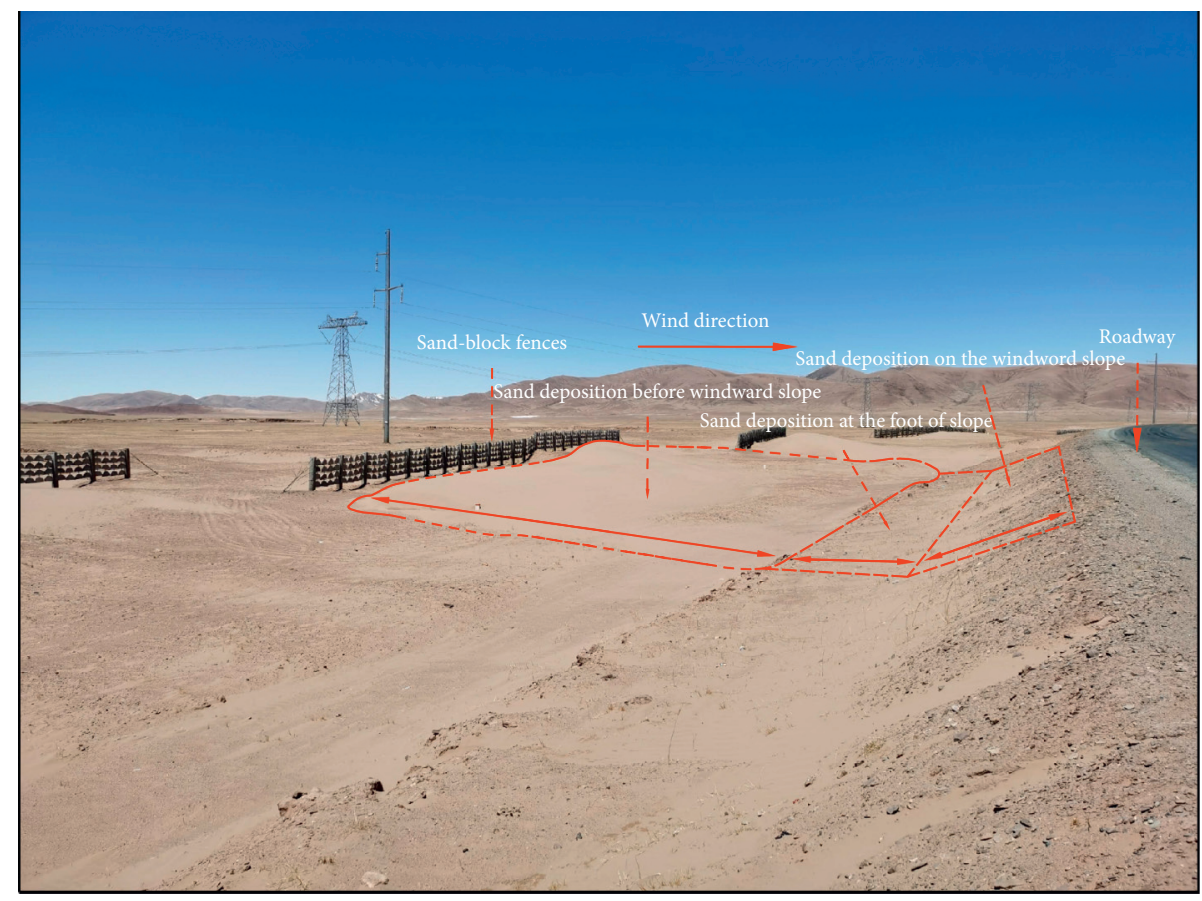

(a)

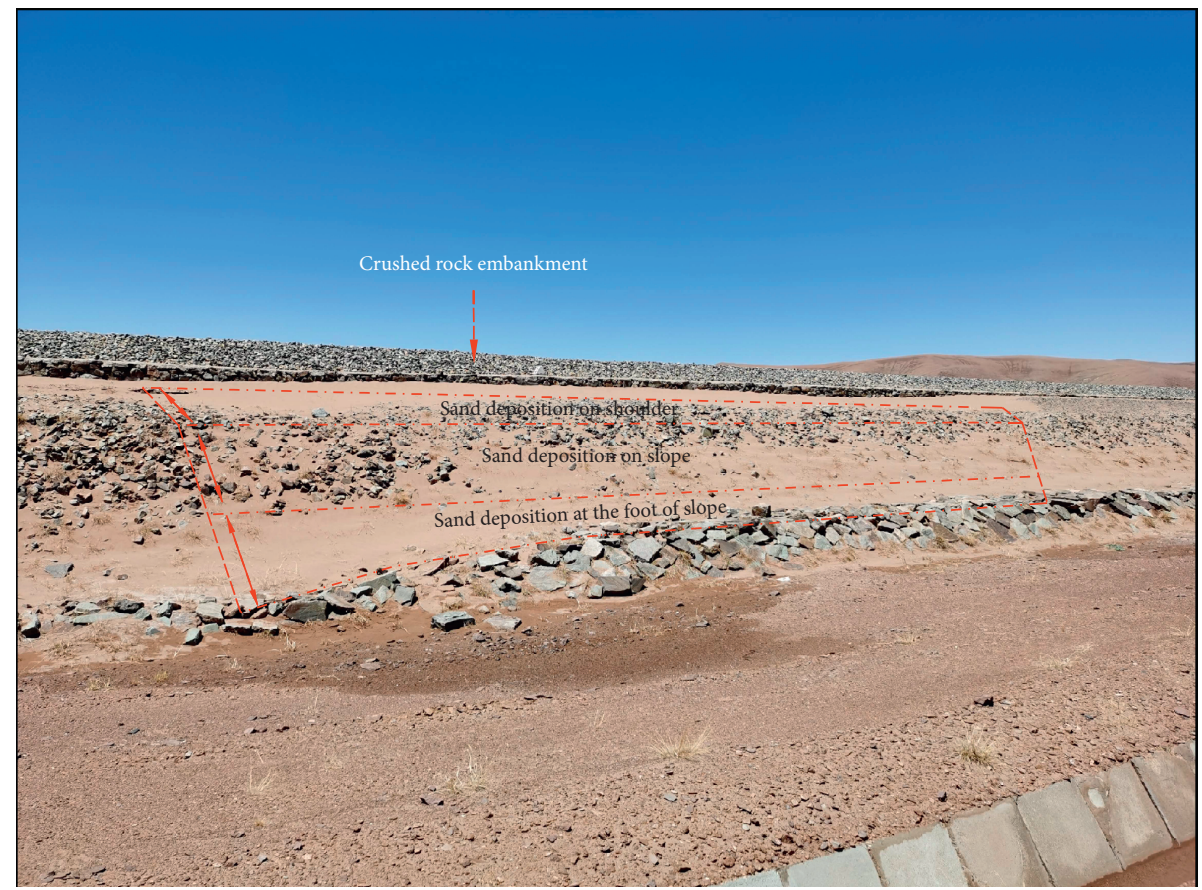

(b)

Figure 1: Wind-blown sand deposition around the embankments of the Qinghai-Tibet Roadway (a) and Qinghai-Tibet Railway (b).

where $T_{m} \pm T$ is the temperature range of phase change; $C_{u}$ and $\lambda_{u}$ are the volume heat capacity and thermal conductivity of unfrozen soil; $C_{f}$ and $\lambda_{f}$ are the volume heat capacity and thermal conductivity of frozen soil; $L$ is the latent heat of phase change per unit volume.
2.2. Physical Model. A physical model of a highway without sand particles deposition near the toe of the embankment (NSE) is shown in Figure 2(a), and a highway with sand particles deposition near the toe of the embankment (SE) in Figure 2(b). In the model, part I is embankment fill, part II 


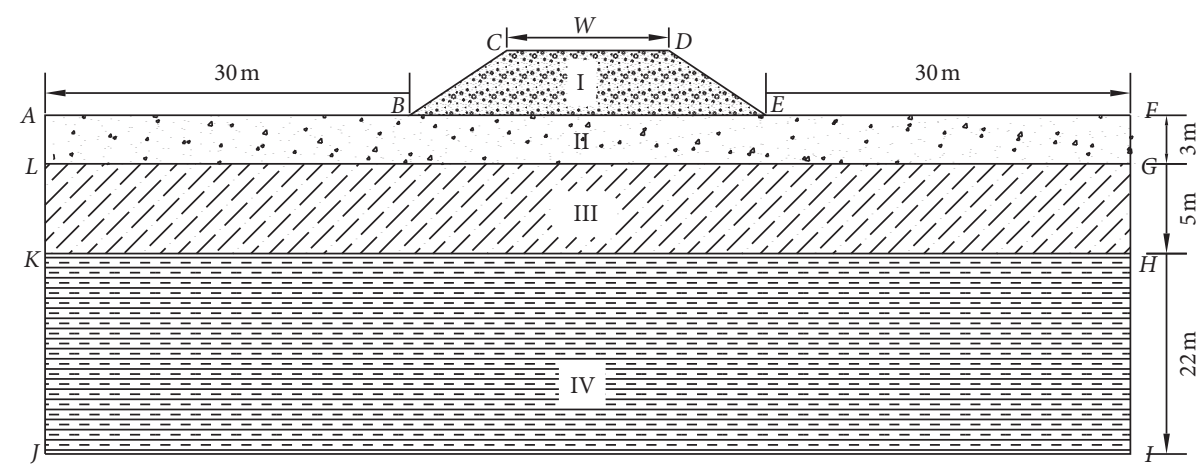

(a)

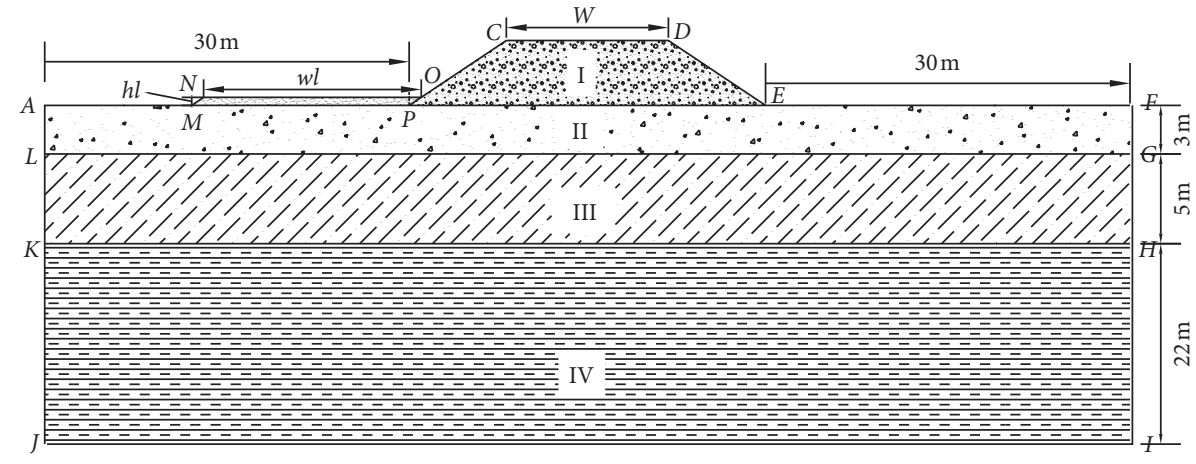

(b)

Figure 2: Schematic diagrams of expressway embankment: (a) no sand embankment; (b) unilateral sand embankment.

$(0 \sim 3 \mathrm{~m})$ is gravel and clayey layer, part III $(3 \sim 8 \mathrm{~m})$ is silty clay, and part $\operatorname{IV}(8 \sim 30 \mathrm{~m})$ is weathered mudstone. The height of the embankment is $4 \mathrm{~m}$ and the width of its paving is $10 \mathrm{~m}$. The gradient of the slope is $1: 1.5$. The widths of the sand deposition are determined as $7.1,10$, and $16.7 \mathrm{~m}$. The thicknesses of sand particles deposition are determined as $0.3,0.5$, and $0.7 \mathrm{~m}$. The computational domain is extended by $30 \mathrm{~m}$ wide from the outside slop toe of the embankment in the horizontal direction and $30 \mathrm{~m}$ height beneath the natural surface in the vertical direction. The thermal parameters of soil layers are given in Table 1 [33].

2.3. Boundary. According to the IPCC report, the air temperature in Qinghai-Tibetan Plateau (QTP) will be warmed up by $2.6^{\circ} \mathrm{C}$ in the future 50 years because of climate change [35]. Based on the adhered layer theory $[12,36]$, the thermal boundary conditions of the computational domain are expressed as follows:

The temperature at natural surfaces of the NSE model ( $\mathrm{AB}$ and $\mathrm{EF}$ ) and the SE model (AM and $\mathrm{EF}$ ) is as follows:

$$
T_{n}=T_{a}+2.5+12.5 \sin \left(\frac{2 \pi}{8760} t_{h}+\frac{\pi}{2}\right)+\frac{2.6}{8760 \times 50} t_{h} .
$$

The temperature at the side slopes of the NSE model (BC and $\mathrm{DE}$ ) and the SE model (OC and DE) is as follows:

$$
T_{s}=T_{a}+4.5+13.5 \sin \left(\frac{2 \pi}{8760} t_{h}+\frac{\pi}{2}\right)+\frac{2.6}{8760 \times 50} t_{h} .
$$

The temperature at the asphalt pavement surface of the NSE model and SE model (CD) is as follows:

$$
T_{p}=T_{a}+6.5+13.9 \sin \left(\frac{2 \pi}{8760} t_{h}+\frac{\pi}{2}\right)+\frac{2.6}{8760 \times 50} t_{h} .
$$

The temperature at the sand particles deposition surface of the SE model (NO and NM) is as follows:

$$
T_{s p}=T_{a}+4.3+14.0 \sin \left(\frac{2 \pi}{8760} t_{h}+\frac{\pi}{2}\right)+\frac{2.6}{8760 \times 50} t_{h},
$$

where $t_{h}$ is the time; $T_{a}$ is the mean annual air temperature at which the embankment is located, being determined as -3.0 , -3.5 , and $-4.0^{\circ} \mathrm{C}$, respectively. The geothermal heat flux of $0.03 \mathrm{~W} / \mathrm{m}^{2}$ is applied to the bottom boundary (IJ) in both models. The lateral boundaries (ALKI and FGHI) are assumed to be adiabatic. With the governing equations and boundary conditions above, the problem is solved numerically using the commercial software of Fluent 14.0.

The temperature boundary of the natural ground surface without consideration of climate warming is used to calculate the initial temperature fields beneath the embankment (parts II, III, and IV). The obtained stable temperature fields on July 15 are taken as the initial temperature condition of these parts, as shown in Figure 3.

2.4. Model Validation. To validate the reliability of the computational model and parameters, numerically simulated results of soil temperature beneath the sand particles 
TABLE 1: Thermal parameters of soil layers.

\begin{tabular}{lccccc}
\hline Physical variable & $\rho_{s}\left(\mathrm{~kg} \cdot \mathrm{m}^{-3}\right)$ & $\lambda_{f} \mathrm{~W} /\left(\mathrm{m} \cdot{ }^{\circ} \mathrm{C}\right)$ & $C_{f} \mathrm{~J} /\left(\mathrm{m}^{3} \cdot{ }^{\circ} \mathrm{C}\right)$ & $\lambda_{u} \mathrm{~W} /\left(\mathrm{m} \cdot{ }^{\circ} \mathrm{C}\right)$ & $C_{u} \mathrm{~J} /\left(\mathrm{m}^{3} \cdot{ }^{\circ} \mathrm{C}\right)$ \\
\hline Embankment fill & 2060 & 1.98 & $1.913 \times 10^{6}$ & 1.92 & $2.22 \times 10^{6}$ \\
Gravel and clayey & 1800 & 1.82 & $9.06 \times 10^{5}$ & 1.60 & $2.04 \times 10^{7}$ \\
Weathered mudstone & 1800 & 1.82 & $1.846 \times 10^{6}$ & 1.47 & $2.09 \times 10^{6}$ \\
Silty clay & 1600 & 1.35 & $1.879 \times 10^{6}$ & 1.13 & $2.73 \times 10^{7}$ \\
Sand & 2650 & 0.258 & $1.610 \times 10^{6}$ & 0.258 & $3.77 \times 10^{7}$ \\
\hline
\end{tabular}

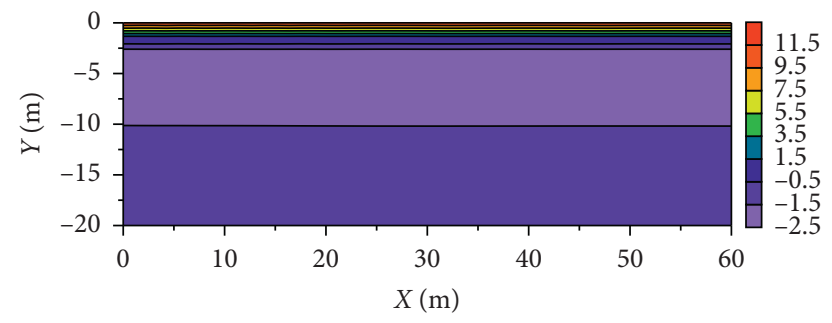

FIgURE 3: Initial temperature condition of parts II, III, and IV (unit: ${ }^{\circ} \mathrm{C}$ ).

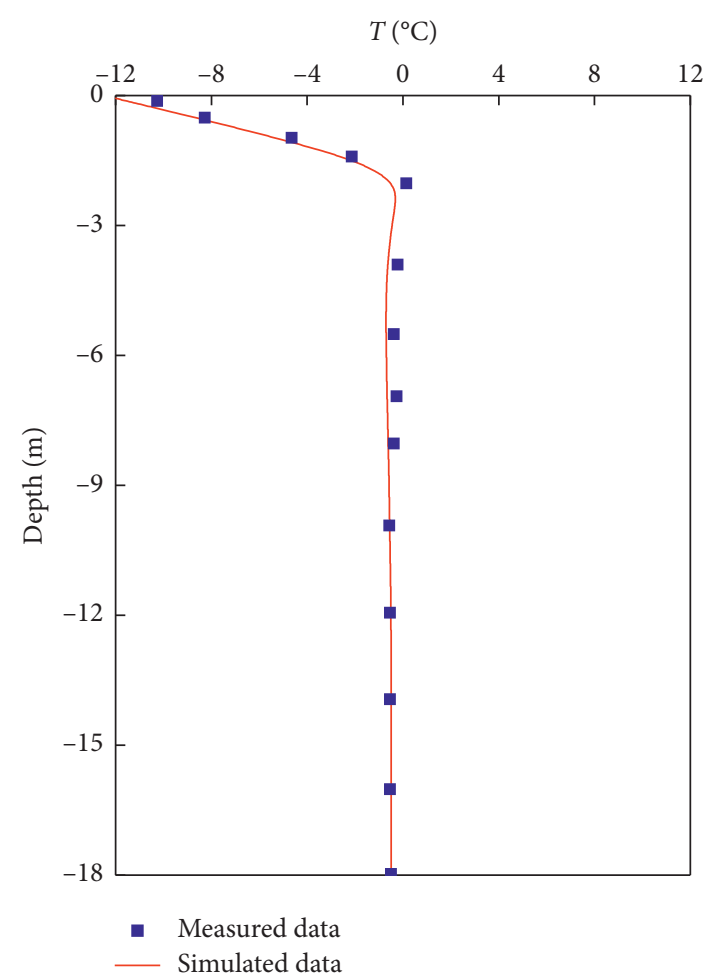

(a)

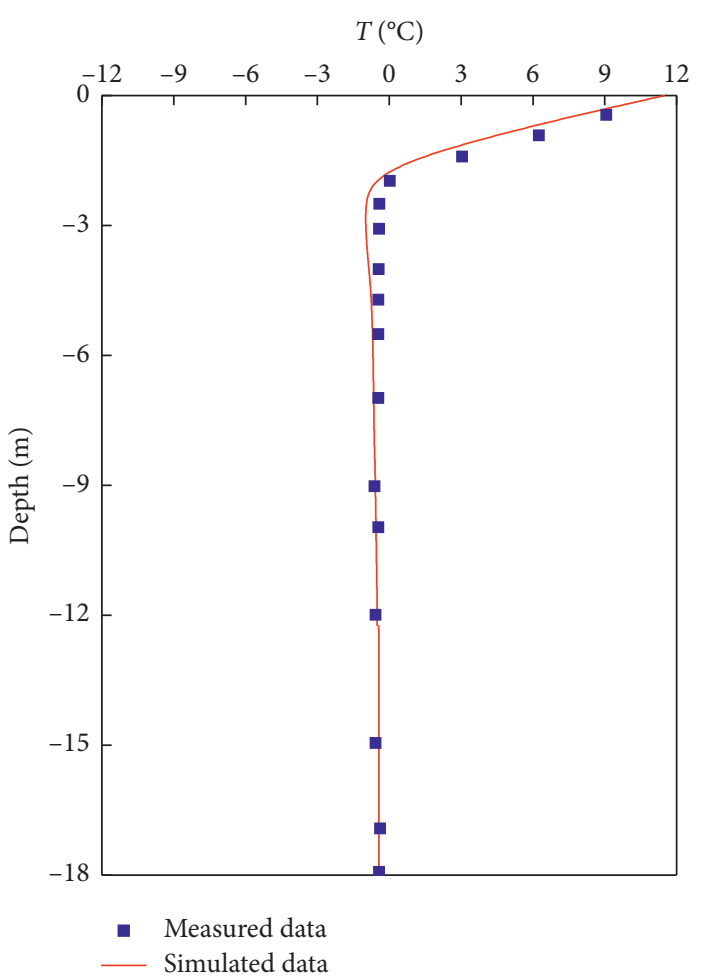

(b)

Figure 4: Field measured and numerically simulated ground temperatures vs. depth at $40 \mathrm{~cm}$ sandy surface on (a) April 15 and (b) July 15.

deposition surface are compared with the field measured data on April 15 and July 15 [37], as shown in Figure 4. It could be seen that the agreement between field measured data and numerically simulated results is good. However, there are some slight discrepancies between the simulated results and field measured data, especially on July 15 . The simulated results of soil temperature are lower than those of the measured data within the active layer. The discrepancies may be attributed to the simplifications of boundary and soil strata in the computational model. Overall, the comparison shows that the computational model and the parameters can be used for simulating the spatial distribution and temporal evolution pattern of temperature beneath the embankment in permafrost zones. 


\section{Results and Analysis}

3.1. Variation of Temperature beneath the Embankment without Sand Deposition. For the NSE, without consideration of the sunny-shady slope effect, Figure 5 shows soil temperature distribution beneath the NSE, in which the embankment is located with different MAGTs, in October 15 in the 5th, 20th, and 50th year after the embankment construction. The soil temperature distribution is given from the centerline of the embankment to $20 \mathrm{~m}$ away from the slop toe (Parts 1-3 in Figure 2(a)).

In the 5th year after the embankment construction (Figure 5(a)), the distribution pattern of the ground temperature field under the NSE in different MAGT permafrost zones is basically the same. The permafrost table beneath the centerline of the embankment (CE) is higher than that beneath the natural surface (NS). As for the permafrost zone with different MAGTs of $-0.5,-1.0$, and $-1.5^{\circ} \mathrm{C}$, the increase of the permafrost table is $0.3,1.6$, and $2.0 \mathrm{~m}$, respectively. In addition, due to the increase in the thermal area of the asphalt pavement of the embankment and the structure, the internal heat absorption of the embankment will increase sharply. The trend of the geothermal line changes in different permafrost zones. In the permafrost zone with the MAGT of $-0.5^{\circ} \mathrm{C}$, it can be seen that the depth of the geothermal line of $-0.4^{\circ} \mathrm{C}$ beneath the NS is the same as that beneath the CE. In contrast, in the permafrost zone with two MAGTs of -1.0 and $-1.5^{\circ} \mathrm{C}$, the depth of the geothermal line of $-0.4^{\circ} \mathrm{C}$ beneath the NS is lower than that beneath CE (Figure 5(a)). It reveals that the thermal disturbance to different MAGT permafrost zones is different in the early stage of embankment construction.

With the operational time increasing, the permafrost table and the permafrost warming beneath the NS and the embankment decline, especially for the CE. The internal heat absorption of the embankment will lead to a significant downward trend of the geothermal line beneath the CE. In the 20th year after construction of the embankment, the permafrost table beneath the NS in the permafrost zone with the MAGT of $-0.5,-1.0$, and $-1.5^{\circ} \mathrm{C}$ is $2.7,2.2$, and $2.0 \mathrm{~m}$, respectively. Meanwhile, the permafrost table beneath the $\mathrm{CE}$ in the permafrost zone with the MAGT of $-0.5,-1.0$, and $-1.5^{\circ} \mathrm{C}$ is $3.8,2.6$, and $1.2 \mathrm{~m}$, respectively (Figure $2(\mathrm{~b})$ ). In the 50 th year after the construction of the embankment, due to the "heat gathering" effect of the asphalt pavement and the structure of the embankment, the permafrost table beneath the CE in permafrost zones with three different MAGTs is lower than that beneath the NS. The difference in the permafrost table is $5.5,2.1$, and $1.7 \mathrm{~m}$, respectively (Figure 5(c)).

Hence, considering the warming of the permafrost beneath NS and the CE in the context of climate warming and human engineering activities, the change rate of the permafrost can be used to evaluate the degradation of the permafrost. The variation of the permafrost table beneath the CE and the NS is listed in Table 2. As for the three different MAGT permafrost zones, it can be seen that the higher the MAGT is, the greater the rate of degradation of the permafrost beneath the CE and NS will be. In addition, with the operation of the embankment, the degradation of permafrost beneath the $\mathrm{CE}$ is higher than that of beneath the NS, which shows the thermal influence of the embankment.

\subsection{Variation of Temperature beneath the Embankment with} Unilateral Sand Deposition. As an obstacle structure, the construction of the embankment will change the progress of the initial flow field, including the wind flow and wind-sand flow. The redistribution of the wind-sand flow around the embankment will influence the capacity of the flow field, resulting in the sand particles deposition around the embankment. In this part, considering the influence of the ambient wind speeds, the difference of sand particles deposition around the embankment is significant, which may affect the temperature beneath the embankment. Hence, the influence of the unilateral sand particles deposition (USPD) at the toe of the embankment with the height of $4 \mathrm{~m}$ is investigated in this part. The width and thickness of the sand layer are $10 \mathrm{~m}$ and $0.5 \mathrm{~m}$, respectively. The variations of the temperature beneath the embankment over the simulation period of 50 years for three initial MAGTs of $-0.5,-1.0$, and $-1.5^{\circ} \mathrm{C}$ are shown in Figures $6-8$.

In the 5 th year after the sand particles deposition at the toe of the embankment, the USPD will induce the asymmetrical distribution of the temperature beneath the embankment. As for three different MAGTs, the lower the MAGT of the permafrost zone is, the more significant the asymmetry along the depth direction will be. From Figure 6, it can be seen that due to the USPD at the toe of the embankment, the maximum depth of zero annual amplitude of ground temperature is offset from the CE. The offsets are 5, 7.5 , and $13.0 \mathrm{~m}$ for three different MAGTs, respectively (Figure 6). Otherwise, the permafrost table beneath the centerline of the sand particles deposition (CSD) has moved $1.0,1.3$, and $1.4 \mathrm{~m}$ above the NS for three different MAGTs, respectively. It reveals that the sand particles deposition can delay the degradation of the permafrost in the early stage of the sand particles deposition.

With sand particles deposition time increasing at the toe of the embankment, the influence of the USPD for the temperature beneath the embankment is different in the three different MAGT permafrost zones. In the 20th year after the sand particles deposition at the toe of the embankment, in the permafrost zone with the MAGTs of $-0.5^{\circ} \mathrm{C}$, the temperature field beneath the embankment is symmetrically distributed with the maximum depth of zero annual amplitude of ground temperature locating at the CE. The influence of the USPD on the temperature beneath the embankment gradually weakens. In contrast, for the permafrost zones of the MAGT of -1.0 and $-1.5^{\circ} \mathrm{C}$, the asymmetrical distribution of the temperature beneath the embankment is still significant. The offsets of the centerline are 3.0 and $5.0 \mathrm{~m}$ for two different MAGTs, respectively (Figure 7). With the sand particles deposition for 20 years, the permafrost table beneath the CSD has moved 0.4, 1.1, and $1.3 \mathrm{~m}$ upward above the NS for three different MAGTs of $-0.5,-1.0$, and $-1.5^{\circ} \mathrm{C}$, respectively. It reveals that with the 

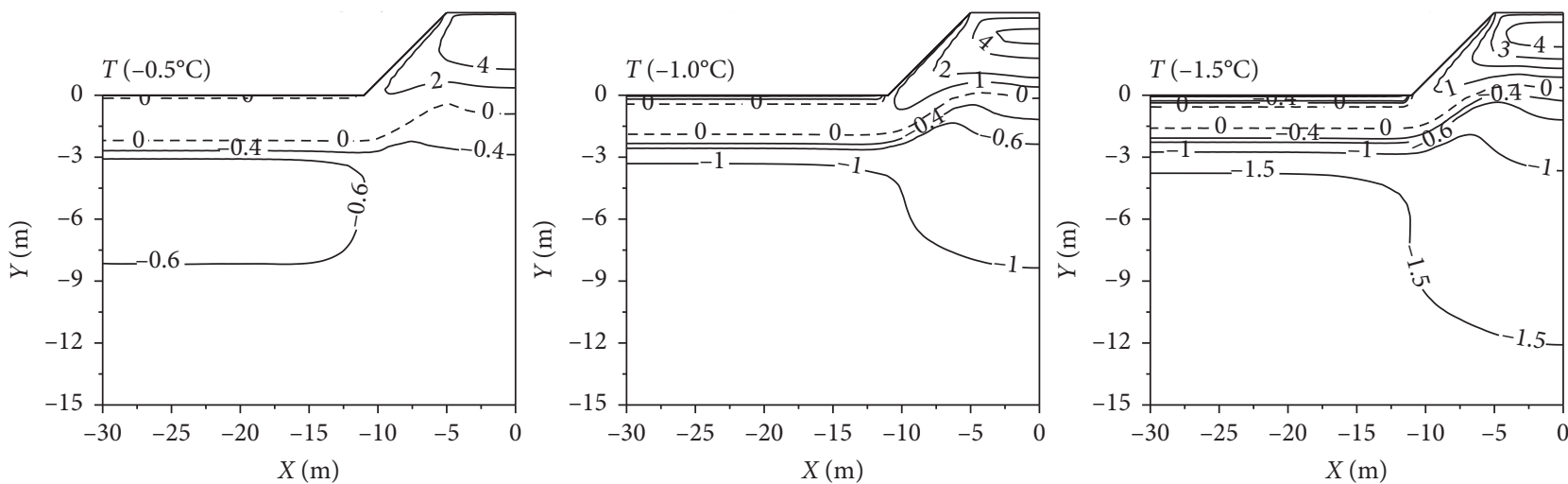

(a)
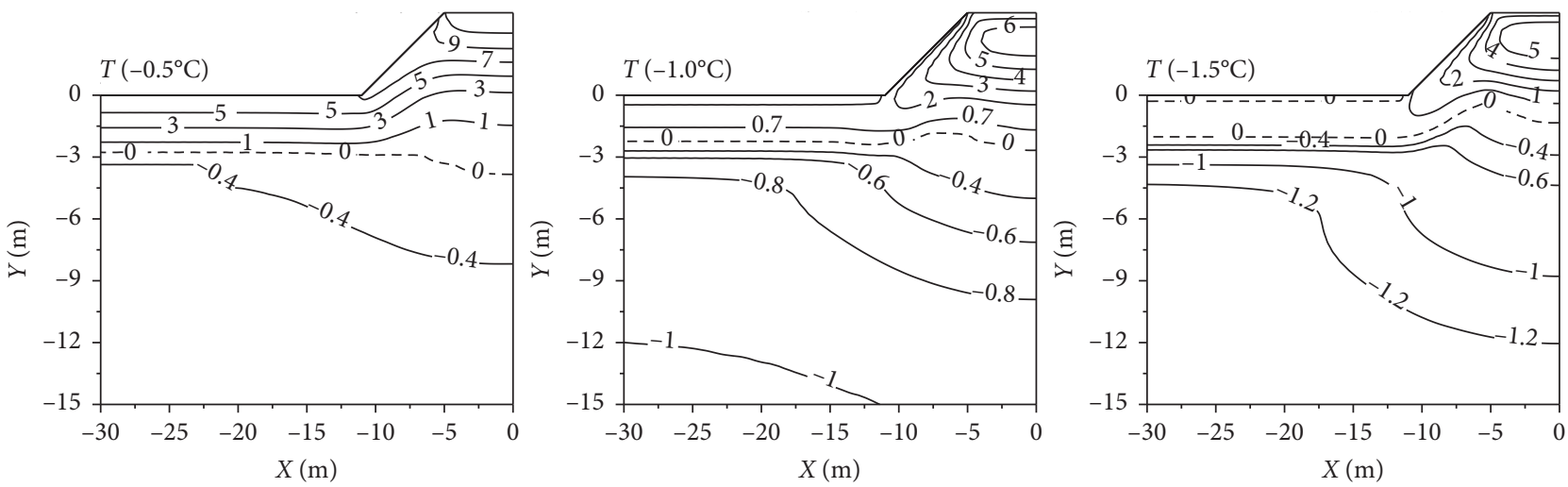

(b)
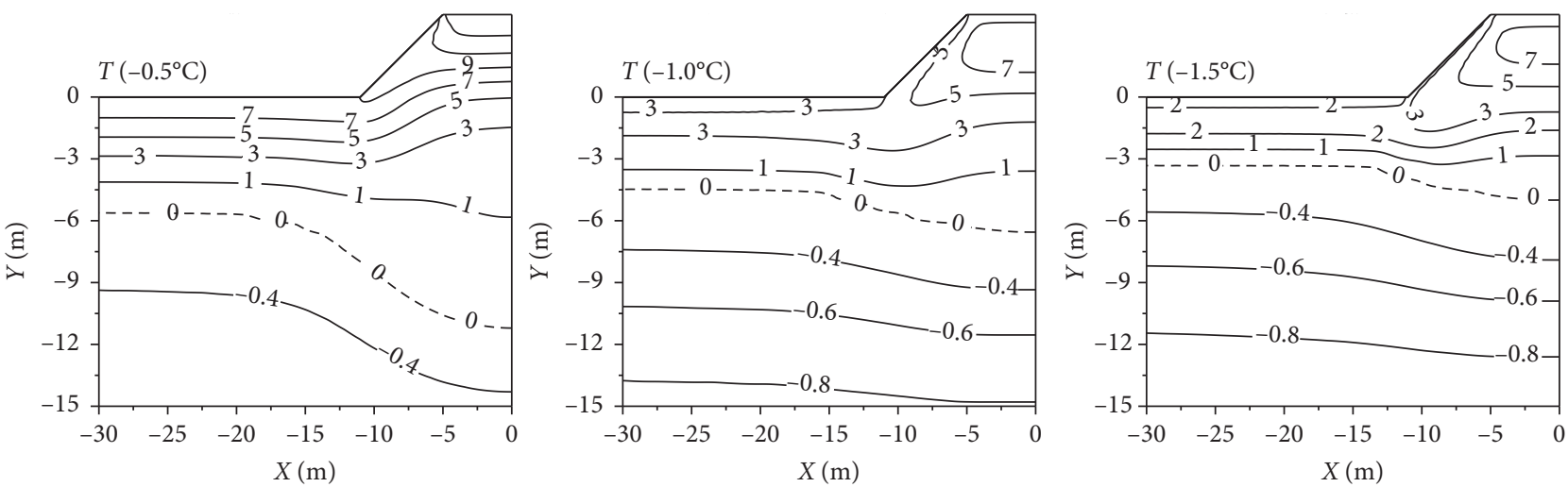

(c)

Figure 5: Distribution of the temperature field beneath the NSE under the annual ground temperature of $-0.5^{\circ} \mathrm{C},-1.0^{\circ} \mathrm{C}$, and $1.5^{\circ} \mathrm{C}$ in October of the 5 th, 20 th, and 50 th years (unit: ${ }^{\circ} \mathrm{C}$ ).

TABLE 2: The change rate of the permafrost table beneath the NS and CE under different mean annual ground temperatures (unit: $\mathrm{m} / \mathrm{a}$ ).

\begin{tabular}{|c|c|c|c|c|c|c|}
\hline \multirow{3}{*}{ Time } & \multicolumn{6}{|c|}{ Temperature } \\
\hline & \multicolumn{2}{|c|}{$-0.5^{\circ} \mathrm{C}$} & \multicolumn{2}{|c|}{$-1.0^{\circ} \mathrm{C}$} & \multicolumn{2}{|c|}{$-1.5^{\circ} \mathrm{C}$} \\
\hline & NS & $\mathrm{EC}$ & NS & $\mathrm{EC}$ & NS & EC \\
\hline $5 \mathrm{a} \sim 20 \mathrm{a}$ & 0.04 & 0.20 & 0.03 & 0.16 & 0.02 & 0.01 \\
\hline $20 \mathrm{a} \sim 50 \mathrm{a}$ & 0.11 & 0.23 & 0.07 & 0.13 & 0.05 & 0.13 \\
\hline
\end{tabular}




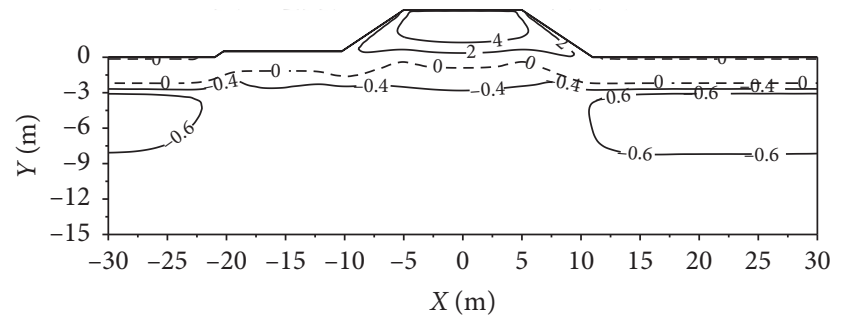

(a)

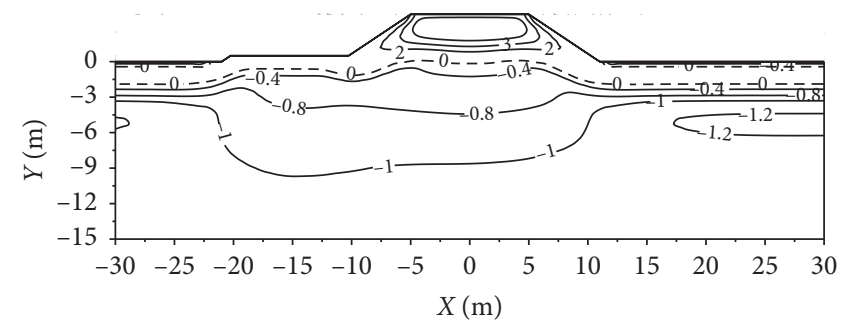

(b)

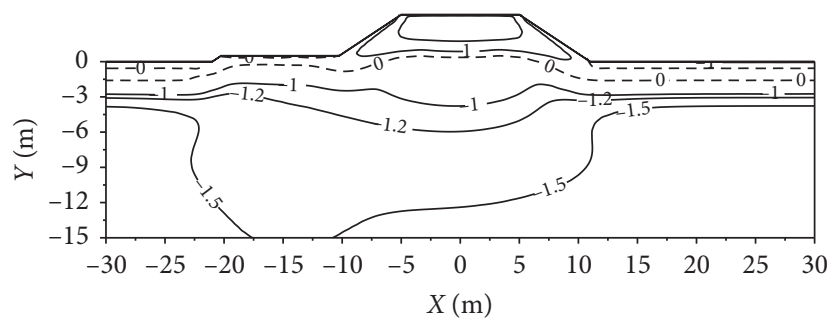

(c)

Figure 6: Distribution of the temperature field beneath the SE in October of the 5th year under the different mean annual ground temperatures: (a) $-0.5^{\circ} \mathrm{C}$, (b) $-1.0^{\circ} \mathrm{C}$, and (c) $-1.5^{\circ} \mathrm{C}$ (unit: ${ }^{\circ} \mathrm{C}$ ).

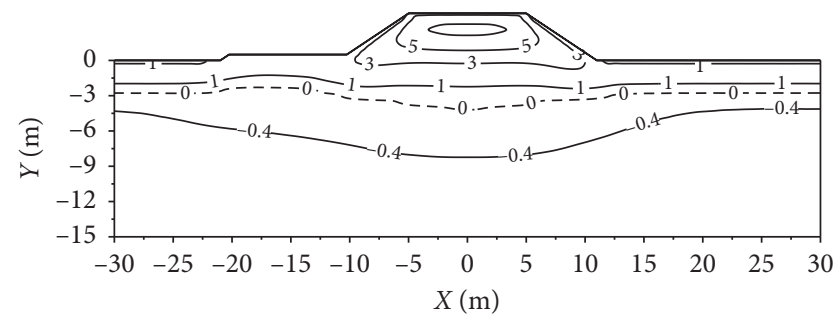

(a)

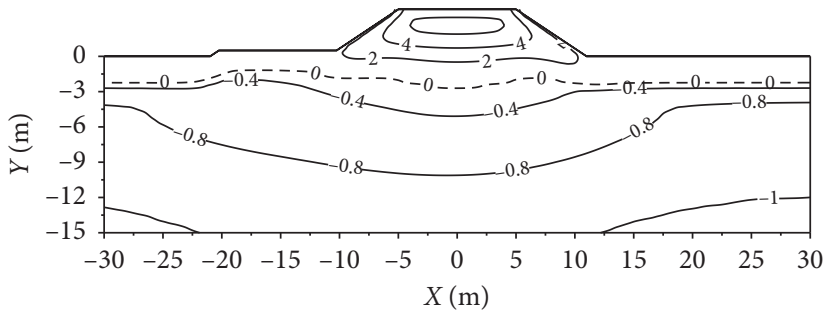

(b)

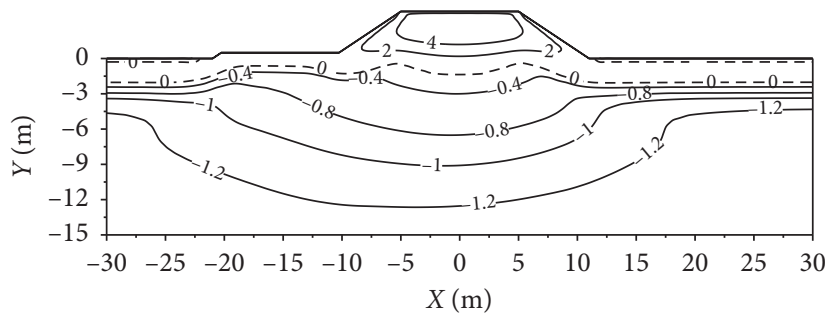

(c)

Figure 7: Distribution of the temperature field beneath the SE in October of the 20th year under the different mean annual ground temperatures: (a) $-0.5^{\circ} \mathrm{C}$, (b) $-1.0^{\circ} \mathrm{C}$, and (c) $-1.5^{\circ} \mathrm{C}$ (unit: ${ }^{\circ} \mathrm{C}$ ).

time of USPD increasing, the sensitivity of the permafrost to sand particles deposition gradually weakens and the protective effect of sand particles deposition on permafrost gradually disappears (Figure 8). In addition, in the 50th year after the sand particles deposition at the toe of the embankment, the influence of the USPD at the toe of the embankment could be ignored for three different MAGT permafrost zones. The distribution of the temperature beneath the embankment is symmetrical. However, with the sand particles deposition lasting for 50 years, the permafrost table beneath the CSD is lower than that beneath the NS in the permafrost zone with MAGT of $-0.5^{\circ} \mathrm{C}$. Meanwhile, the permafrost table beneath the centerline of the sand particles deposition is basically the same as the NS for the two MAGTs of -1.0 and $-1.5^{\circ} \mathrm{C}$, respectively (Figure 9). Thus, by comparing the variation of the permafrost beneath the sand particles deposition and the NS in three different MAGTs, it could be found that with the time of sand particles at the toe of the embankment increasing, the asymmetrical distribution of the temperature beneath the embankment is gradually weakening. What is more, the influence of the sand particles deposition can mitigate the degradation of the permafrost beneath it, especially for the permafrost zone with the MAGRs of -1.0 and $-1.5^{\circ} \mathrm{C}$. Within 50 years of the 


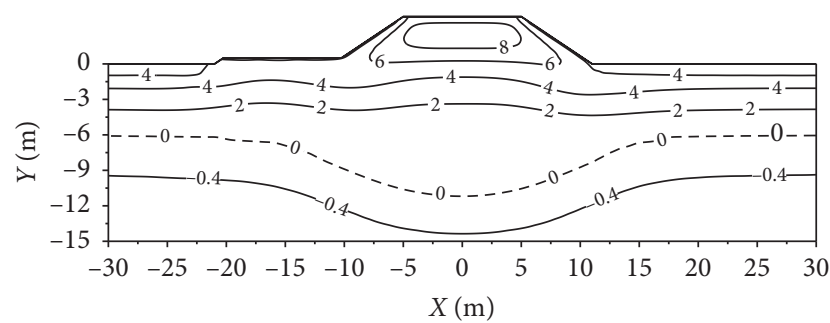

(a)

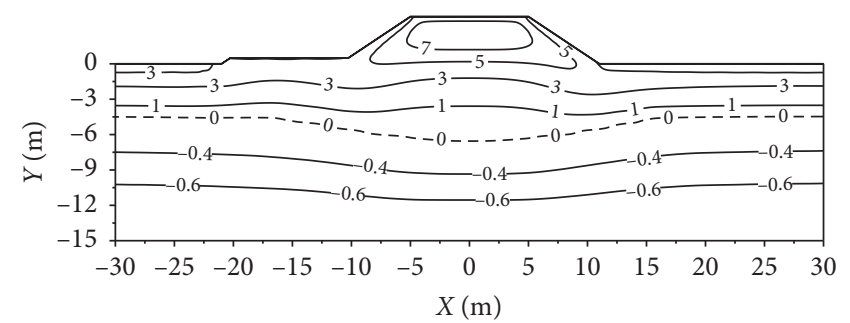

(b)

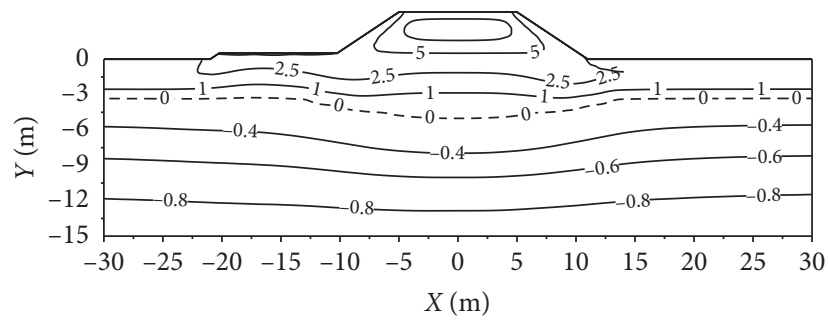

(c)

Figure 8: Distribution of the temperature field beneath the SE in October of the 50th year under the different mean annual ground temperatures: (a) $-0.5^{\circ} \mathrm{C}$, (b) $-1.0^{\circ} \mathrm{C}$, and (c) $-1.5^{\circ} \mathrm{C}$ (unit: ${ }^{\circ} \mathrm{C}$ ).

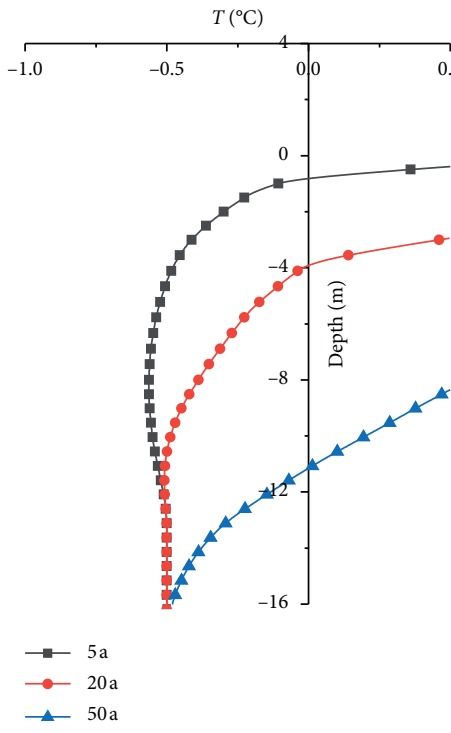

(a)

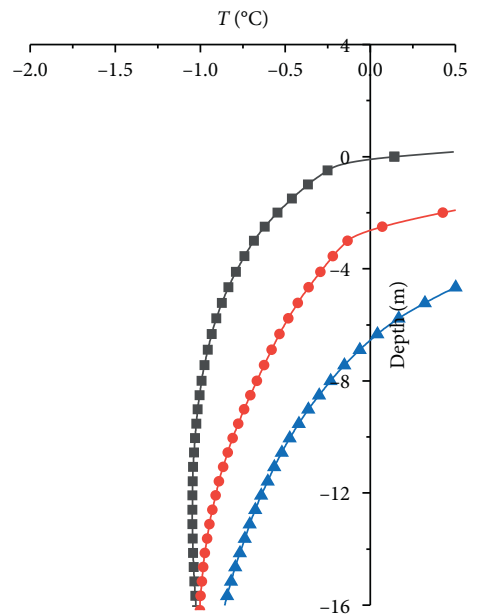

$\rightarrow 5 \mathrm{a}$
$\rightarrow-20 \mathrm{a}$
$\rightarrow 50 \mathrm{a}$

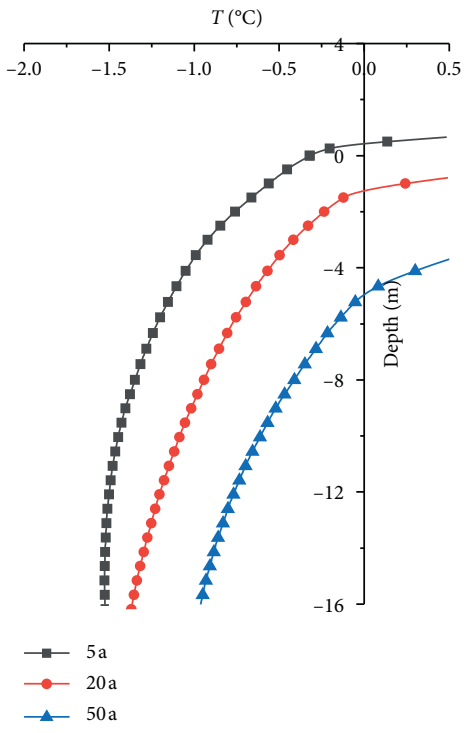

(c)

Figure 9: Variation in soil temperature beneath the CE in October of the 5th, 20th, and 50th years under different mean annual ground temperatures: (a) $-0.5^{\circ} \mathrm{C}$, (b) $-1.0^{\circ} \mathrm{C}$, and (c) $-1.5^{\circ} \mathrm{C}$.

sand particles deposition, the permafrost table beneath the CSD is higher than that beneath the NS (Table 3).

\subsection{Effect of Unilateral Sand Particles Deposition on Tem-} perature at Different Locations around the Embankment. The variations of the temperature beneath the $\mathrm{CE}$ and the toe of the embankment (TES), at which the sand particles are deposited, are shown in Figures 9 and 10. It could be seen that with the increase of time, the variations of the temperature beneath different surface boundaries in three different MAGT permafrost zones vary significantly. In
Figures 9 and 10, it can be seen that 50 years after the sand particles deposition at the toe of the embankment, the maximum depth of zero annual amplitude of ground temperature beneath the CE and TES is about 16 and $14 \mathrm{~m}$, respectively. Compared with the embankment without sand particles deposition at the toe, the sand particles deposition has little influence on the value of the maximum depth of zero annual amplitude of ground temperature.

Additionally, Tables 4 and 5 show the variation of the permafrost table beneath the CE and CES (the center of the embankment without sand particles deposition), TES and the toe without sand particles deposition (TE) in October of 
TABLE 3: Variation of the permafrost table under different boundaries (unit: $\mathrm{m}$ ).

\begin{tabular}{|c|c|c|c|c|c|c|}
\hline \multirow{2}{*}{ Temperature } & \multicolumn{3}{|c|}{ NS } & \multicolumn{3}{|c|}{ CSD } \\
\hline & $5 \mathrm{a}$ & $20 a$ & $50 a$ & $5 \mathrm{a}$ & $20 \mathrm{a}$ & $50 \mathrm{a}$ \\
\hline$-1.0^{\circ} \mathrm{C}$ & 2.0 & 2.2 & 4.4 & 1.0 & 1.6 & 4.5 \\
\hline$-1.5^{\circ} \mathrm{C}$ & 1.6 & 2.0 & 3.2 & 0.6 & 1.0 & 3.4 \\
\hline
\end{tabular}

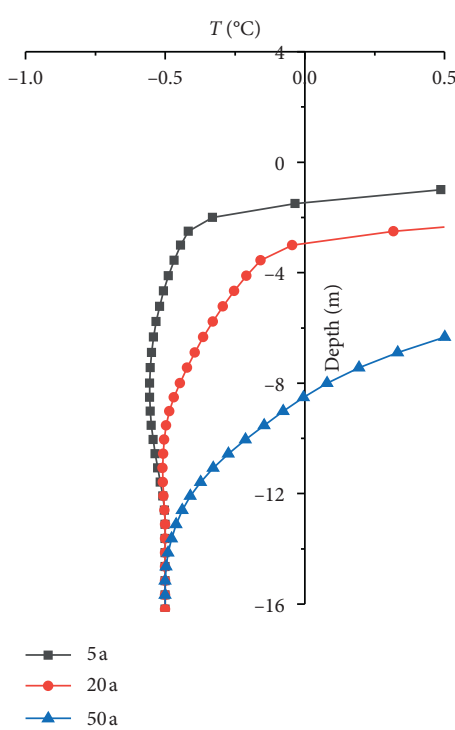

(a)

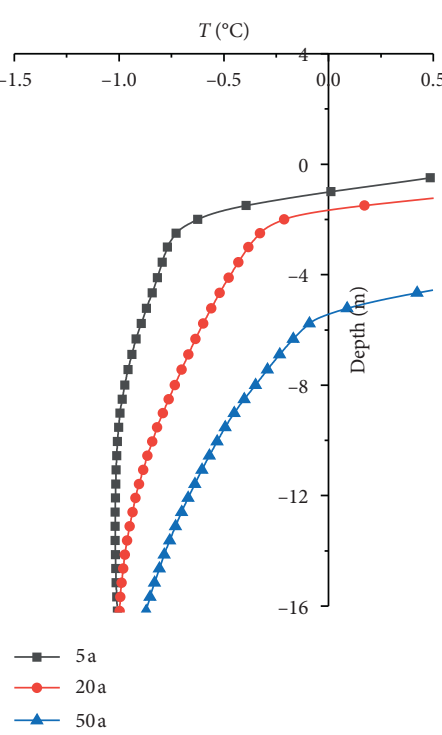

(b)

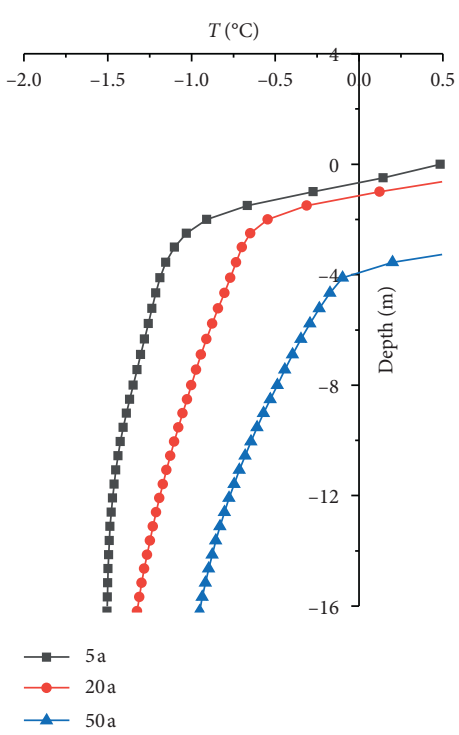

(c)

FiguRE 10: Variation in soil temperature beneath the TE in October of the 5th, 20th, and 50th years under different mean annual ground temperatures: (a) $-0.5^{\circ} \mathrm{C}$, (b) $-1.0^{\circ} \mathrm{C}$, and (c) $-1.5^{\circ} \mathrm{C}$.

TABLE 4: Variation of the table permafrost beneath the CE and CES under different mean annual ground temperatures (unit: $\mathrm{m}$ ).

\begin{tabular}{lcccccc}
\hline \multirow{2}{*}{ Temperature } & \multicolumn{3}{c}{$\mathrm{CE}$} & \multicolumn{3}{c}{$\mathrm{CES}$} \\
& $5 \mathrm{a}$ & $20 \mathrm{a}$ & $50 \mathrm{a}$ & $5 \mathrm{a}$ & $20 \mathrm{a}$ & $50 \mathrm{a}$ \\
\hline$-0.5^{\circ} \mathrm{C}$ & -0.88 & -3.98 & -11.18 & -0.79 & -4.15 & -11.25 \\
$-1.0^{\circ} \mathrm{C}$ & -0.10 & -2.60 & -6.52 & -0.11 & -2.73 & -6.60 \\
$-1.5^{\circ} \mathrm{C}$ & +0.45 & -1.27 & -4.99 & +0.41 & -1.27 & -4.95 \\
\hline
\end{tabular}

TABLE 5: Variation of the table permafrost beneath the TE and TES under different mean annual ground temperatures (unit: $\mathrm{m}$ ).

\begin{tabular}{lcccccc}
\hline \multirow{2}{*}{ Temperature } & \multicolumn{3}{c}{ TE } & & \multicolumn{3}{c}{ TES } \\
& $5 \mathrm{a}$ & $20 \mathrm{a}$ & $50 \mathrm{a}$ & $5 \mathrm{a}$ & $20 \mathrm{a}$ & $50 \mathrm{a}$ \\
\hline$-0.5^{\circ} \mathrm{C}$ & -2.19 & -3.28 & -8.32 & -1.52 & -2.99 & -8.53 \\
$-1.0^{\circ} \mathrm{C}$ & -1.84 & -2.40 & -5.57 & -1.04 & -1.72 & -5.50 \\
$-1.5^{\circ} \mathrm{C}$ & -1.55 & -2.01 & -3.84 & -0.64 & -1.20 & -3.99 \\
\hline
\end{tabular}

the 5th, 20th, and $50^{\text {th }}$ years with three different MAGTs. Comparing the permafrost table beneath the CE and CES with different MAGTs and times, it can be found that the USPD at the toe of the embankment has little influence on the variation of the permafrost table beneath the $\mathrm{CE}$
(Table 4). However, as for the toe of the embankment (Table 5), 5 years after the sand particles deposition, the permafrost table beneath the toe of TES in three different MAGTs is $1.52,1.04$, and $0.64 \mathrm{~m}$, the value of which is 0.67 , 0.80 , and $0.91 \mathrm{~m}$ higher than that beneath the TE, respectively. With the sand particles deposition increasing to 20 years, the permafrost table beneath the TES is $0.29,0.68$, and $0.81 \mathrm{~m}$ higher than that beneath the TE, respectively. Moreover, after 50 years of the sand particles deposition, the value of the increase is $-0.21,0.00$, and $-0.15 \mathrm{~m}$, respectively. Hence, from the result of the comparison between the permafrost table beneath the TES and TE, it could be found that as for the three different MAGTs permafrost zones, the USPD at the toe of the embankment has a significant influence on the permafrost table beneath the toe of embankment. From the 5 th year of sand particles deposition to 20th year, the sand particles deposition could improve the permafrost table beneath the toe of the embankment, especially for the permafrost zone with the MAGT of $-1.5^{\circ} \mathrm{C}$. However, with the time of sand particles deposition increasing, the influence of the sand particles deposition may induce the temperature of permafrost to increase and accelerate the degradation of the permafrost. Hence, as for the permafrost zone with different MAGTs, the adoption of sand 


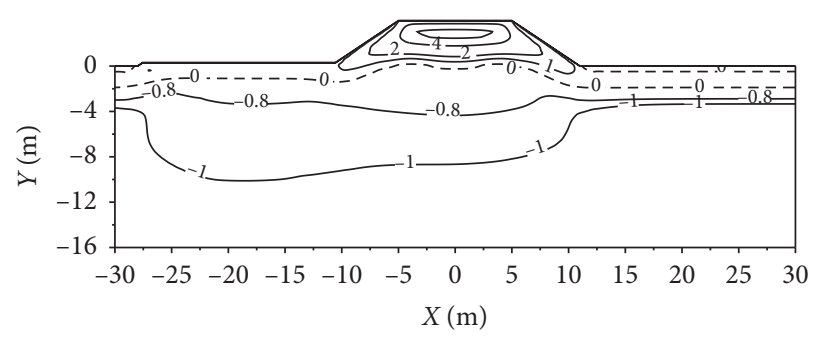

(a)

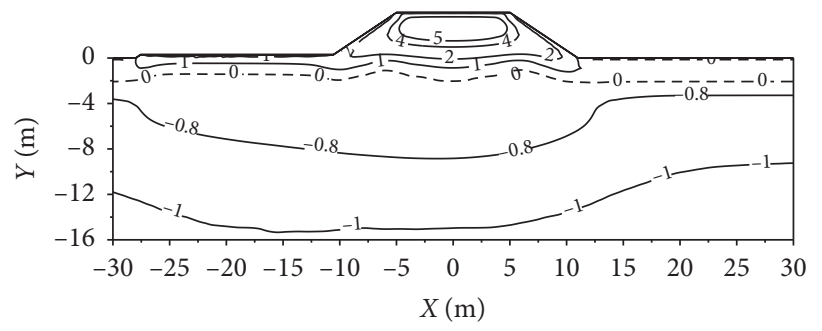

(c)

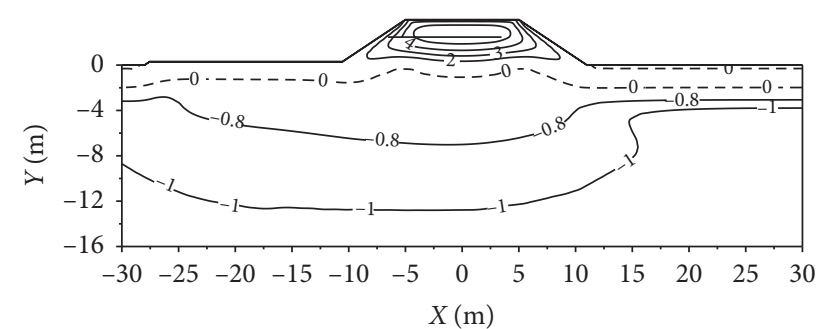

(b)

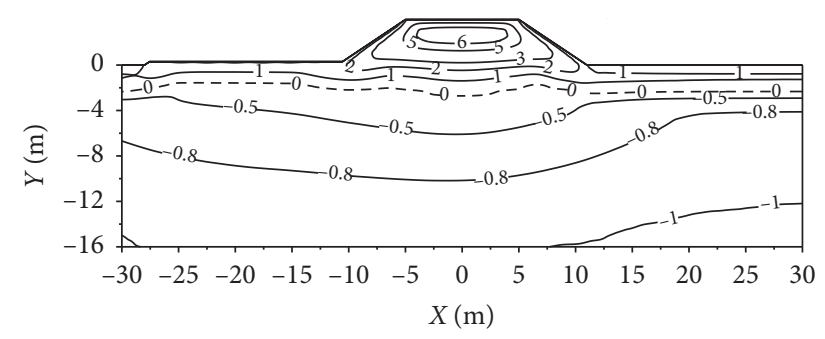

(d)

FIgURE 11: Distribution of the temperature field beneath the SE with the sand deposition thickness of $0.3 \mathrm{~m}$ in cold season of $5 \mathrm{a}, 10 \mathrm{a}, 15 \mathrm{a}$, and 20 a (unit: ${ }^{\circ} \mathrm{C}$ ).

control measures is beneficial to protect the permafrost by considering the time of sand particles deposition around the embankment.

\subsection{Effect of Different Forms of Sand Particles Deposition on} the Temperature of Permafrost. Based on the study in the previous section, it can be concluded that within 20 years of the sand particles deposition, the sand particles deposition has a significant protective effect on the permafrost beneath it. Hence, in order to study the thermal effects of different forms of sand particles deposition (thick and thin of the sand layer) on the permafrost, under the condition of the MAGT $-1.0^{\circ} \mathrm{C}$, the thermal effects of sand particles deposition on the permafrost ground temperature with different thin and thick of the sand layer are given in Figures 11 and 12 .

In Figure 11, with the thickness of the sand layer being $0.3 \mathrm{~m}$, the isotherms beneath the toe of the embankment with sand particles deposition vary significantly, inducing the asymmetrical distribution of the geothermal field beneath the embankment. The depths of $-1.0^{\circ} \mathrm{C}$ isotherm beneath the NS are compared, which are $5 \mathrm{~m}$ away from the two toes of the embankment. The depth of the $-1.0^{\circ} \mathrm{C}$ isotherm beneath the toe without sand particles deposition has moved $6.5,4.0,3.3$, and $1.7 \mathrm{~m}$ upward compared with the toe with $0.3 \mathrm{~m}$ thick sand layer after the sand particles deposition of $5,10,15$, and 20 years, respectively. In addition, in Figure 12, with the thickness of sand layer being $0.7 \mathrm{~m}$, it can be found that the distribution of the ground temperature field is basically the same as that of the $0.3 \mathrm{~m}$ condition. As for the $-1.0^{\circ} \mathrm{C}$ isotherm, the depth of it beneath the toe without sand particles deposition has moved $4.8,2.8,1.4$, and $1.3 \mathrm{~m}$ upward compared with the toe with $0.7 \mathrm{~m}$ thick sand layer after the sand particles deposition of 5, 10, 15, and 20 years, respectively. This means that with the time of the sand particles deposition increasing, the "wide and thin" type of sand particles deposition has a greater influence on the depth of the lower ground temperature field than that of the "narrow and thick" type of sand particles deposition.

To investigate permafrost warming beneath different thin and thick sand layers in the context of climate warming, the variations of the permafrost table beneath the CE, TE, TES, and CSD are shown in Tables 6 and 7 within 20 years of the sand particles deposition. It could be found that the two different sand particles deposition forms have less effect on the variation of permafrost table beneath $\mathrm{CE}$ and TE. However, there is a significant effect on the permafrost table beneath the CSD and TES. In Table 6, with the thickness of the sand layer being $0.3 \mathrm{~m}$, the degradation rate of the permafrost beneath the CSD, TES, and TE is 0.03 , 0.05 , and $0.04 \mathrm{~m} \cdot \mathrm{a}^{-1}$, respectively. Additionally, in Table 7 , with the thickness of the sand layer being $0.7 \mathrm{~m}$, the degradation rate of the permafrost beneath the CSD, TES, and TE is $0.03,0.04$, and $0.04 \mathrm{~m} \cdot \mathrm{a}^{-1}$, respectively. This means that, within 20 years of sand particles deposition, no matter which form of the sand layer is, the deposition of the sand particles could weaken the degradation rate of the permafrost. However, as for the TES, the more the thickness of the sand layer, the smaller the degradation rate of permafrost.

As for the embankment in the permafrost zone, the main disease is thaw collapse, which is closely related to the variation of the permafrost table. After 5 years of the two forms of sand particles deposition ("wide and thin" and "narrow and thick"), the difference of the permafrost table, the location of which is beneath the two toes of the embankment, between the two toes of the embankment is 0.49 and $0.88 \mathrm{~m}$, respectively (Tables 6 and 7). However, the 


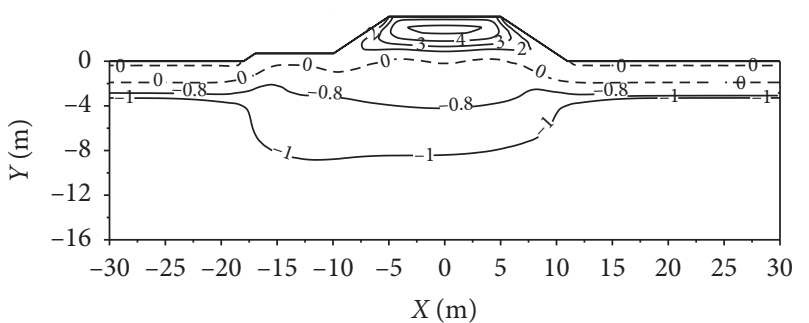

(a)

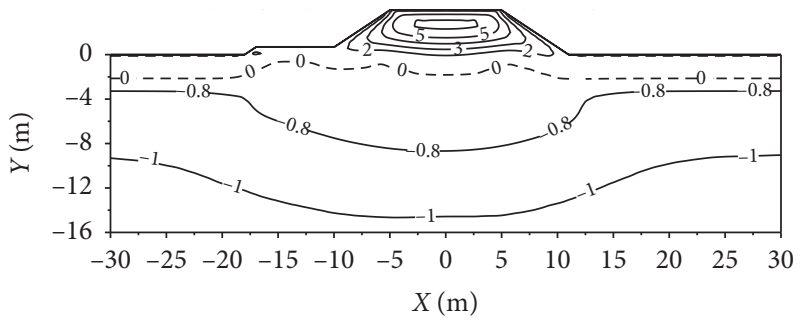

(c)

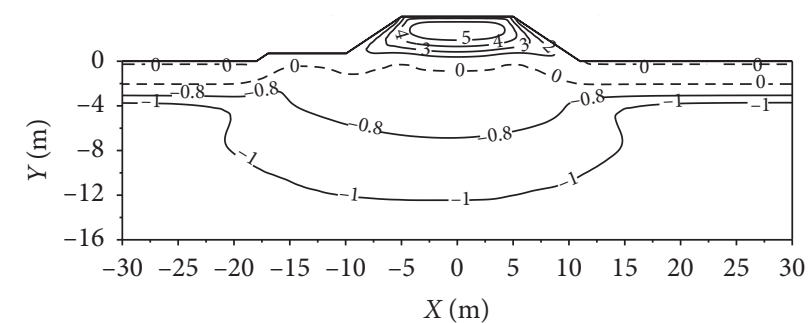

(b)

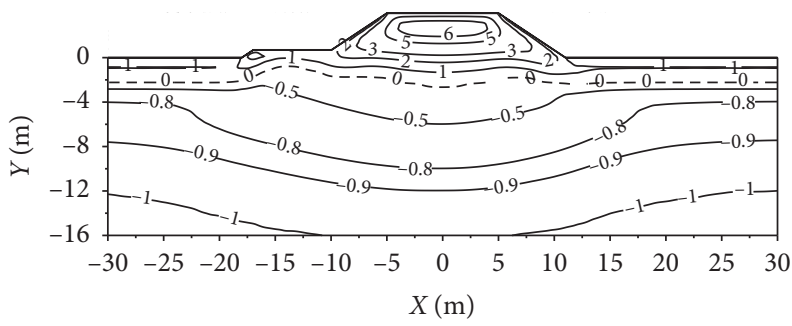

(d)

Figure 12: Distribution of the temperature field beneath the SE with the sand deposition thickness of $0.7 \mathrm{~m}$ in cold season of $5 \mathrm{a}, 10 \mathrm{a}, 15 \mathrm{a}$, and 20 a (unit: ${ }^{\circ} \mathrm{C}$ ).

TABLE 6: Variation of the permafrost table beneath the SE with the sand thickness of $0.3 \mathrm{~m}$ in October 15th of 5th, 10th, 15th, and 20th years (unit: $\mathrm{m}$ ).

\begin{tabular}{lcccc}
\hline Temperature & CE & TE & TES & CSD \\
\hline $5 \mathrm{a}$ & -0.23 & -1.89 & -1.40 & -1.08 \\
$10 \mathrm{a}$ & -1.05 & -1.99 & -1.53 & -1.27 \\
$15 \mathrm{a}$ & -2.00 & -2.13 & -1.93 & -1.46 \\
$20 \mathrm{a}$ & -2.69 & -2.45 & -2.23 & -1.55 \\
\hline
\end{tabular}

TABLE 7: Variation of the permafrost table beneath the SE with the sand thickness of $0.7 \mathrm{~m}$ in October 15 th of $5 \mathrm{th}, 10 \mathrm{th}, 15 \mathrm{th}$, and 20th years (unit: $\mathrm{m}$ ).

\begin{tabular}{lcccc}
\hline Temperature & CE & TE & TES & CSD \\
\hline $5 \mathrm{a}$ & -0.19 & -1.88 & -1.00 & -0.31 \\
$10 \mathrm{a}$ & -0.88 & -2.01 & -1.12 & -0.46 \\
$15 \mathrm{a}$ & -1.83 & -2.16 & -1.29 & -0.61 \\
$20 \mathrm{a}$ & -2.61 & -2.48 & -1.64 & -0.78 \\
\hline
\end{tabular}

degradation rate of the permafrost table with the sand layer thickness of $0.3 \mathrm{~m}$ is greater than that with the sand layer thickness of $0.7 \mathrm{~m}$. With the sand particles deposition time increasing and the context of the climate warming, the difference of permafrost table between two toes of the embankment will induce uneven settlement significantly, especially for the embankment with the "narrow and thick" sand particles deposition at the toe of the embankment. Hence, in order to reduce its impact on the long-term thermal condition beneath the embankment, it was necessary to clean the thicker deposition sand particles at the toe of the embankment.

\section{Conclusion}

In permafrost areas, the engineering activities will have a considerable influence on the project and the underlying permafrost. As an engineering structure, the constructions of the road project will produce certain disturbance to the original relatively stable wind-sand flow along the route, leading to the redistribution of the flow field around the embankment and the emergence of sand particles deposition. The deposition and coverage of sand particles around the embankment can change the thermal conditions of the permafrost embankment. In this article, a mathematical model of heat transfer for freeze-thaw soil is constructed to investigate the long-term thermal effects of sand particles deposition at the toe of the embankment in the permafrost with different MAGTs. Based on the above numerical analyses and comparisons, the following conclusions can be drawn:

(1) The thermal disturbance of the construction of the embankment in the permafrost zone with different MAGTs varies significantly. With time increasing, the degradation rate of the permafrost largely differs in different parts around the embankment. After 50 years of the construction of the embankment, the permafrost table beneath the $\mathrm{CE}$ in the permafrost zones with three different MAGTs is 11.5, 6.5, and $5.0 \mathrm{~m}$. In contrast, the value of which beneath the NS is $6.0,6.5$, and $5.0 \mathrm{~m}$. Therefore, the construction of the highway embankment will increase the heat absorption within the embankment and accelerates permafrost degradation. 
(2) The influence of the USPD will induce the distribution of the temperature beneath the embankment asymmetry significantly, especially for the embankment in the permafrost with different MAGTs. The lower the MAGT of the permafrost, the more significant the asymmetry of the temperature distribution. With the time of sand particles deposition increasing, the asymmetry of ground temperature field in three different MAGTs weakens gradually. Moreover, The influence of the sand particles deposition can mitigate the degradation of the permafrost beneath it, especially for the permafrost zone with the MAGRs of -1.0 and $-1.5^{\circ} \mathrm{C}$. Within 50 years of the sand particles deposition, the permafrost table beneath the CSD is higher than that beneath the NS.

(3) From the variation of the temperature distribution at different parts of the embankment, the influence of the USPD on the permafrost table beneath the CE could be ignored. In contrast, for the TES, with the time of sand particles deposition increasing, the degradation rate of permafrost table at the TES is greater than that at the TE, especially for permafrost with the MAGT $-0.5^{\circ} \mathrm{C}$. After 50 years of the sand particles deposition at the toe of the embankment, the permafrost table has moved $0.21 \mathrm{~m}$ upward beneath the TE compared with that beneath the TES.

(4) With different sand thickness and width conditions, the effect of "narrow and thick" form sand particles deposition on the temperature field beneath embankment was greater than that of "wide and thin" form sand deposition. Hence, in order to reduce its impact on the long-term thermal condition beneath the embankment, it was necessary to clean the thicker deposition sand particles at the toe of the embankment.

\section{Data Availability}

The data used to support the findings of this study are available from the corresponding author upon request.

\section{Conflicts of Interest}

The authors declare that they have no conflicts of interest related to this manuscript.

\section{Acknowledgments}

This research was supported by the Natural Science Foundation of China (41630636 and 41772325) and the Research Project of the State Key Laboratory of Frozen Soils Engineering (SKLFSE-ZY-17).

\section{References}

[1] M. Wei, F. J. Niu, and Y. H. Mu, "Basic research on the major permafrost projects in the Qinghai-Tibet plateau," Advance Earth Science, vol. 11, no. 27, pp. 1185-1191, 2012.
[2] G. D. Cheng and T. H. Wu, "Responses of permafrost to climate change and their environmental significance, Qinghai-Tibet Plateau," Journal of Geophysical Research, vol. 112, 2007.

[3] J. W. Harden, C. D. Koven, C. L. Ping et al., "Field information links permafrost carbon to physical vulnerabilities of thawing," Geophysical Research Letters, vol. 39, 2012.

[4] M. Sivakumar, "Interactions between climate and desertification," Agricultural and Forest Meteorology, vol. 142, no. 2, pp. 143-155, 2007.

[5] Q. B. Wu, W. B. Yu, and H. J. Jin, "No protection of permafrost due to desertification on the Qinghai-Tibet Plateau," Scientific Reports, vol. 7, no. 1, 2017.

[6] S. Xie, J. Qu, and Y. Pang, "Dynamic wind differences in the formation of sand hazards at high- and low-altitude railway sections," Journal of Wind Engineering and Industrial Aerodynamics, vol. 169, pp. 39-46, 2017.

[7] Q. H. Yu, W. Gu, J. Qian, J. M. Zhang, and X. C. Qian, "Problem analysis of high-grade highway construction in permafrost regions," Highways, vol. 11, pp. 74-80, 2010.

[8] Q. H. Yu, K. Fan, J. Qian, L. Guo, and Y. H. You, "Key issues of highway construction in permafrost regions in China," Science China Press: Technological Science, vol. 44, no. 4, pp. 425-432, 2014.

[9] W. Ma, Y. H. Mu, S. B. Xie, Y. C. Mao, and D. Chen, "Thermal-mechanical influences and environmental effects of expressway construction on the Qinghai-Tibet permafrost engineering corridor," Advances in Earth Science, vol. 32, no. 5, pp. 459-464, 2017.

[10] Z. Zhou, W. Ma, S. Zhang, H. Du, Y. Mu, and G. Li, "Multiaxial creep of frozen loess," Mechanics of Materials, vol. 95, pp. 172-191, 2016.

[11] Z. Zhou, W. Ma, S. Zhang, Y. Mu, and G. Li, "Effect of freezethaw cycles in mechanical behaviors of frozen loess," Cold Regions Science and Technology, vol. 146, pp. 9-18, 2018.

[12] W. Pei, L. Jin, M. Zhang, S. Li, and Y. Lai, "Study of the timedependent thermal behavior of the multilayer asphalt concrete pavement in permafrost regions," Construction and Building Materials, vol. 193, pp. 162-172, 2018.

[13] G. Cheng, "A roadbed cooling approach for the construction of Qinghai-Tibet Railway," Cold Regions Science and Technology, vol. 42, no. 2, pp. 169-176, 2005.

[14] G. Doré, F. Niu, and H. Brooks, "Adaptation methods for transportation infrastructure built on degrading permafrost," Permafrost and Periglacial Processes, vol. 27, no. 4, pp. 352364, 2016.

[15] D. J. Goering and P. Kumar, "Winter-time convection in open-graded embankments," Cold Regions Science and Technology, vol. 24, no. 1, pp. 57-74, 1996.

[16] S. A. Harris and D. E. Pedersen, "Thermal regimes beneath coarse blocky materials," Permafrost and Periglacial Processes, vol. 9, no. 2, pp. 107-120, 1998.

[17] Y. Lai, W. Pei, and W. Yu, "Calculation theories and analysis methods of thermodynamic stability of embankment engineering in cold regions," Chinese Science Bulletin, vol. 59, no. 3, pp. 261-272, 2014.

[18] W. Ma, G. D. Cheng, and Q. B. Wu, "Construction on permafrost foundations: lessons learned from the Qinghai-Tibet railroad," Cold Regions Science and Technology, vol. 59, no. 1, pp. 3-11, 2009.

[19] Q. B. Wu, Y. Z. Liu, J. M. Zhang, and C. J. Tong, "A review of recent frozen soil engineering in permafrost regions along Qinghai-Tibet highway, China," Permafrost and Periglacial Processes, vol. 13, no. 3, pp. 199-205, 2002. 
[20] H. J. Jin, Q. H. Yu, and S. L. Wang, "Changes in permafrost environments along the Qinghai-Tibet engineering corridor induced by anthropogenic activities and climate warming," Cold Regions Science and Technology, vol. 53, no. 3, pp. 317-333, 2008.

[21] M. X. Yang, S. L. Wang, T. D. Yao, X. H. Gou, A. X. Lu, and X. J. Guo, "Desertification and its relationship with permafrost degradation in Qinghai-Xizang (Tibet) plateau," Cold Regions Science and Technology, vol. 39, no. 01, pp. 47-53, 2004.

[22] S. B. Xie, J. J. Qu, B. Liu, and X. T. Xu, "Advance in research on the sand hazards and its control along the Qinghai-Tibet railway," Journal of Desert Research, vol. 34, no. 01, pp. 42-48, 2014.

[23] S. L. Wang, L. Zhao, and S. X. Li, "Interaction between permafrost and desertification on the Qinghai-Tibet plateau," Journal of Desert Research, vol. 1, pp. 33-39, 2002.

[24] J. Malenfant-Lepage, G. Doré, D. Fortier, and P. Murchison, "Thermal performance of the permafrost protection techniques at Beaver Creek experimental road site, Yukon, Canada," in Proceedings of the 10th International Conference on Permafrost, Salekhard, Russia, June-2012.

[25] S. B. Xie, J. J. Qu, Y. M. Lai, X. T. Xu, and Y. J. Pang, "Key evidence of the role of desertification in protecting the underlying permafrost in the Qinghai-Tibet Plateau," Scientific Reports, vol. 5, 2015.

[26] K. C. Zhang, J. J. Qu, K. T. Liao, Q. H. Niu, and Q. J. Han, "Damage by wind-blown sand and its control along QinghaiTibet Railway in China," Aeolian Research, vol. 1, no. 3, pp. 143-146, 2010.

[27] L. Chen, W. B. Yu, C. S. Yang, X. Yi, and W. B. Liu, "Conductivity of aeolian sand on the Tibet Plateau based on microstructure," Journal of Glaciology and Geocryology, vol. 36, no. 5, pp. 1220-1226, 2014.

[28] W. Yu, W. Liu, L. Chen, X. Yi, F. Han, and D. Hu, "Evaluation of cooling effects of crushed rock under sand-filling and climate warming scenarios on the Tibet Plateau," Applied Thermal Engineering, vol. 92, pp. 130-136, 2016.

[29] L. Chen, W. B. Yu, F. L. Han, W. B. Liu, and X. Yi, "Impacts of aeolian sand on cooling effect of crushed-rock embankment of Qinghai-Tibet Railway," Journal of Glaciology and Geocryology, vol. 37, no. 1, pp. 147-155, 2015.

[30] L. Chen, W. Yu, X. Yi, D. Hu, and W. Liu, "Numerical simulation of heat transfer of the crushed-rock interlayer embankment of Qinghai-Tibet Railway affected by aeolian sand clogging and climate change," Cold Regions Science and Technology, vol. 155, pp. 1-10, 2018.

[31] W. D. An, Z. W. Wu, and W. Ma, Interaction Among Temperature, Moisture and Stress fields in Frozen Soil, Lanzhou University Press, Lanzhou, China, 1990.

[32] Y. Lai, Q. Wang, F. Niu, and K. Zhang, "Three-dimensional nonlinear analysis for temperature characteristic of ventilated embankment in permafrost regions," Cold Regions Science and Technology, vol. 38, no. 2-3, pp. 165-184, 2004.

[33] J. M. Zhang, J. Z. Zhang, and Y. Z. Liu, "Study on the reasonable embankment height of Qinghai-Tibet railway in permafrost regions," China Railway Science, vol. 27, no. 5, pp. 28-34, 2006.

[34] M. Zhang, X. Zhang, S. Li, D. Wu, W. Pei, and Y. Lai, "Evaluating the cooling performance of crushed-rock interlayer embankments with unperforated and perforated ventilation ducts in permafrost regions," Energy, vol. 93, pp. 874-881, 2015.
[35] D. H. Qin, The Comprehensive Evaluating Report on the Environment Evolvement in West China, Science Press, Beijing, China, 2002.

[36] L. N. Zhu, "Study of the adherent layer on different types of ground in permafrost regions on the Qinghai-Xizang Plateau," Journal of Glaciology and Geocryology, vol. 10, no. 1, pp. 8-14, 1988.

[37] L. Y. Wang, Q. B. Wu, and G. L. Jiang, "Numerical simulation of the effect of aeolian sand accumulation on permafrost," Journal of Glaciology and Geocryology, vol. 40, no. 4, pp. 738-747, 2018. 